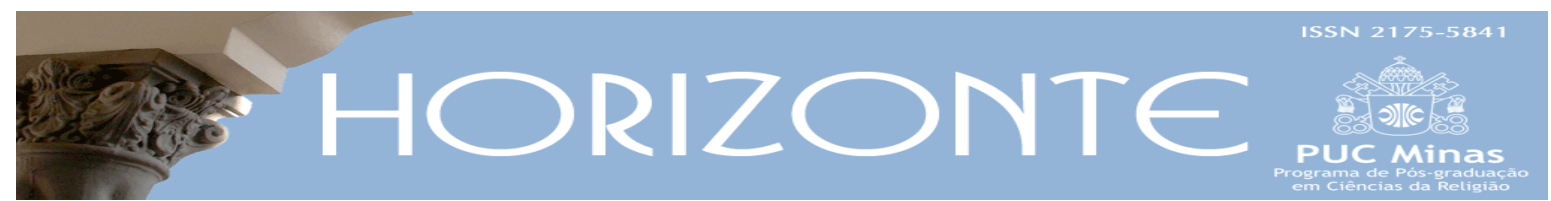

Dossiê: Ordens Religiosas Medievais: Poder e Sociedade - Artigo Original (c) $\underset{\mathrm{EY}}{\mathrm{i}}$ DOI - 10.5752/P.2175-5841.2017v15n48p1191

\title{
O lugar da imagem pictórica e da espiritualidade junto aos Templários e Hospitalários: estado da questão no espaço francês ${ }^{1}$
}

\author{
Wall Paintings and Spirituality in the Templars and Hospitallers: a status \\ quaestionis for France
}

Damien Carraz *

\section{Resumo}

Este artigo sublinha, em primeiro lugar, as divisões historiográficas que conduziram alguns pesquisadores a abordar a espiritualidade e a liturgia das ordens militares sem mesmo suspeitar da riqueza das imagens atestas nos espaços das comendadorias. Por seu lado, certos estudos conduzidos pelos historiadores da arte sobre os conjuntos pictóricos conservados nas capelas conventuais ignoravam largamente o contexto histórico e as características do monasticismo militar. À escala da França atual, se propõe a seguir um balanço, necessariamente provisório, do corpus iconográfico, atestado entre o século XII e o início do XIV, para as igrejas do Templo e do Hospital. O inventário dos lugares de imagens conservados não apenas é provisório, mas assaz pouco significativo, pois ele reflete, sobretudo, o estado da pesquisa - que tende mais a privilegiar o Templo - e que novas descobertas podem sempre aumentar o corpus conhecido. De um ponto de vista cronológico, se resta traços relativamente esparsos das decorações ornamentais da segunda metade do século XIII, um número não negligenciável de decorações figuradas conservadas se concentra no último terço do século XIII. Estes lugares de imagens têm apresentado especificidades ligadas à originalidade da vida regular que era seguida no seio das comendadorias? Em outros termos, as ordens militares foram portadoras de uma cultura visual ou de um pensamento figurativo próprios?

Palavras Chave: Ordens Militares; pinturas murais; espiritualidade; iconografia; França

\begin{abstract}
The articles points out the historiographical partitionings which have led scholars to deal with spirituality and liturgy of the military orders without even suspecting the rich visual background of the commanderies. On their side, most of Art historians have studied the paintings of the conventual chapels without considering their historical background and, above all, the deep originality of military monasticism. It is possible then to offer an assessment, necessarily temporary, on the iconographic corpus preserved for the Templars and the Hospitallers in current France. The inventory of the painted images which have been preserved is not only provisory; it is not entirely significant as it is mostly reflecting the state of researches and as new findings can always enlarge the known material. From a chronological perspective, some scattered traces of ornamental decorations are remaining from the second half of the twelfth century, but most of the figurative images can be assigned to the last decades of the thirteenth century. Are these lieux d'images (using a french concept) revealing specificities which could be linked to the peculiar regular life which was followed in the commanderies? In other words, was the visual culture or the figurative thought of the military orders somehow distinctive?
\end{abstract}

Keywords: Military Orders; wall paintings; spirituality; iconography; France

\footnotetext{
Artigo submetido em 25 de julho de 2017 e aprovado em 28 de dezembro de 2017. Traduzido do francês para o português pelo Prof. Dr. Bruno Tadeu Salles (UFOP). É um primeiro esboço de reflexão que se inscreve no quadro de uma publicação coletiva, oriunda de duas jornadas de estudos organizadas respectivamente em Nanterre (4 de abril de 2014) e em Clermont-Ferrand ( 7 de novembro de 2014). As atas foram publicadas: CARRAZ \& DEHOUX, 2016.

* Doctorat en histoire médiévale en 2003 à l'université Lyon. Université Blaise Pascal - Clermont-Ferrand 2 - Co-responsable du master MEEF et responsable de la formation à l'agrégation (depuis 2014). Co-responsable des stages d'archéologie des Licences 2-3. Secrétaire des Cahiers de Fanjeaux. País de origem: França. E-mail: damien.carraz@wanadoo.fr
}

Horizonte, Belo Horizonte, v. 15, n. 48, p. 1191-1219, out./dez. 2017 - ISSN 2175-5841 


\section{Introdução}

Na França, foi desde o início dos anos 1990 que os historiadores medievalistas apreenderam as imagens para lhes aplicar questionamentos resolutamente históricos, às vezes, antropológicos, sem renegar as contribuições de uma História da Arte que foi, por seu lado, fundamentalmente renovada (BASCHET, 1998; BASCHET, \& RIGAUX, 2008; VOYER, 2010). Ultrapassando uma visão essencialmente formal, semântica e simbólica, historiadores como Jean-Claude Schmitt e Jérôme Baschet sublinharam o caráter performativo das "imagensobjeto": pintadas ou esculpidas em uma habitação senhorial ou, mais frequentemente, em uma igreja, elas permitiam hierarquizar os espaços e serviam de suporte a diversos rituais, em primeiro lugar, aqueles da liturgia cristã (BASCHET, 2008) ${ }^{2}$. Uma tal abordagem, que não dissociaria a imagem de seu contexto material - o manuscrito, ou melhor, o lugar no qual ela se inscreve permitiu renovar o conhecimento sobre a "cultura visual" das ordens religiosas. A partir de análises seriais de imagens de diversas naturezas, Dominique DonadieuRigaut mostrou, por exemplo, como as principais ordens religiosas se representavam em ordo no seio da Igreja universal, nuançando a oposição entre monges e frades mendicantes (DONADIEU-RIGAUT, 2005).

A pesquisa sobre as ordens militares permaneceu por muito tempo apartada destas renovações heurísticas favoráveis à descompartimentalização das abordagens. De fato, certa tradição, presente notadamente na Península Ibérica, se mostrou sensível a "arte junto às ordens militares", dedicando bastante atenção ao fim da Idade Média e à época moderna3. Mas, trata-se de uma abordagem muito clássica, pouco preocupada em integrar as imagens em seu contexto sócio-político e de se interrogar sobre a especificidade das obras ligadas aos frades. Hoje em dia, se o inventário do patrimônio artístico legado por certas ordens ainda está em curso,

\footnotetext{
${ }^{2}$ Mesmo que não se limite a imagem a única dimensão performativa na realização do ritual cristão, sobre o lugar da imagem na liturgia, é necessário ter como ponto de partida os trabalhos de Éric Palazzo (2010).

${ }^{3} \mathrm{~A}$ produção é demasiado importante para ser apreciada aqui. Limitemo-nos a citar um colóquio fundador e um artigo recente, mas em um espírito bem tradicional: Francisco Javier Pizarro Gomes (1985) e Luis Afonso (2005).
} 
como para os Teutônicos na Itália (ROSSI VAIRO, 2008 e 2012), a reunião de um considerável corpus de pinturas murais tem autorizado uma primeira tentativa de síntese para o Templo (CURZI, 2002). Mesmo se se restringe às ordens do Templo e do Hospital, que unicamente nos ocuparão aqui, a tarefa para recensear as imagens que estavam espalhadas nos ambientes dos frades é imensa. As pinturas murais são certamente as mais conhecidas, mas é necessário considerar a pintura no tecido, a escultura, os objetos litúrgicos e outras imagens de devoção, os livros iluminados e, até mesmo, os selos4. Notadamente, essas fontes iconográficas variadas, até então, não suscitaram uma verdadeira reflexão sobre o estatuto e sobre a função da imagem-objeto junto às ordens militares, quando os estudos sobre a espiritualidade e a liturgia, em compensação, se multiplicaram.

Nestas páginas, eu não tenho outra ambição que propor uma breve consideração sobre o assunto, restrito ao caso da pintura mural em França. De um ponto de vista cronológico, o corpus de imagens atualmente conhecido se remete essencialmente ao século XIII, tendo sido conservados poucos traços anteriores. As pinturas do fim da Idade Média ligadas a Ordem do Hospital, por sua parte, podem se mostrar suficientemente numerosas, mas suscitaram pouco interesse. No interior das comendadorias, as imagens eram vistas no seio de muitos lugares onde elas deviam responder a funções litúrgicas ou sociais variadas: este é o caso das salas identificadas como capitulares em Metz e em Cahors (CURZI, 2002, p. 68; MATTALIA, 2013, vol. 1, p. 236) ou da aula onde os Templários ministravam a justiça em Montfrin, na Gard (CARRAZ \& ASPORD, 2010, p. 301). Os espaços privativos recebiam igualmente decorações das quais nada se sabe para a Idade Média central, como no palácio dos Hospitalários de Manosque, onde, em 1289, aparece uma "camera picta ante cameram viridem" (CARRAZ, no prelo). Para uma época mais tardia, sabe-se que os cômodos privados dos comendadores eram decorados com cenas cujas temáticas eram claramente aristocráticas, como em

\footnotetext{
${ }^{4}$ Apenas os selos têm sido verdadeiramente considerados, mas, para outros questionamentos relativos a "Selbstbild", às representações que as ordens militares forjaram delas mesmas: Roman Czaja \& Jürgen Sarnowsky (2005), especificamente os artigos de Jürgen Sarnowsky, Zsolt Hunyadi e Julian Kreem.
} 
Chaynat (Puy-de-Dôme) ou em Soulomès, em Quercy (AGOSTINO, 2004, p. 84; CZERNIAK, 2007). Todavia, as decorações conservadas hoje em dia se concentram essencialmente nos lugares de culto.

Em um primeiro momento, estabeleceremos um paralelo entre duas historiografias que, durante muito tempo, se ignoraram: de um lado, a tradição dos estudos de pinturas murais conduzidos em um quadro monográfico pelos historiadores da arte, pouco informados sobre as ordens militares; de outro lado, as reflexões recentemente abertas sobre a religiosidade dos frades, mas com dificuldades para renovar seu fundo documental e suas abordagens conceituais. Apresentar-se-á, em seguia, um panorama sobre o corpus de pinturas conhecidas, sublinhando os problemas da cronologia. Após uma breve consideração sobre os temas iconográficos privilegiados pelos Templários e pelos Hospitalários, nós terminaremos com algumas considerações sobre o destino destas imagens e sobre os seus comanditários.

\section{Da espiritualidade das ordens militares à iconografia das capelas conventuais: a necessidade da descompartimentalização.}

Se se toma como ponto de partida a ideia de que a imagem é um objeto sagrado, dotado de uma virtus e eventualmente de uma dimensão performativa, é nossa abordagem da espiritualidade dos frades que esta fonte, de início, é suscetível enriquecer. A partir dos anos 1990, a pesquisa dedicada às ordens militares começou a se interrogar sobre as sensibilidades religiosas dos frades que seguiam esta forma um pouco particular de vida regular (ELM, 1992). Numerosos trabalhos efetuados sobre as fontes normativas ajudaram a romper com uma visão folclórica dos Templários e de seus émulos, integrando definitivamente estas diferentes ordens na dinâmica da vita regularis (TOOMASPOEG, 2005). Paralelamente, interessou-se pelo culto das relíquias e dos santos, sendo necessário aqui remeter-se, sobretudo, aos trabalhos de Francesco Tommasi (1989) e de Helen Nicholson (2002 e 2005). 
Outros autores investigaram particularmente a espiritualidade templária, muito marcada pelo culto da cruz, e insistiram particularmente sobre o cristocentrismo dos frades (LICENCE, 2005; PURKIS, 2008, p.98-111; SCHENK, 2011 e 2012). Enfim, recentemente, a história dos Templários e dos Hospitalários experimentaram igualmente um certo "liturgic turn": uma nova geração de pesquisadores se dedicou sobre as práticas litúrgicas dos frades a partir de alguns raros manuscritos litúrgicos conhecidos (DONDI, 1994 e 2010) e dos inventários de livros e de ornamentos conservados nas capelas conventuais (SALVADO, 2010 e 2011).

Entretanto, malgrado algumas tentativas recentes (MATTALIA, vol.1, p. 279285), não é possível determinar se a liturgia das ordens militares encontrou alguma tradução nos dispositivos arquiteturais de seus lugares de culto. Nós avançamos pouco mais com a iconografia. O estudo das imagens é, de fato, a grande ausência dos trabalhos sobre a espiritualidade e a liturgia dos Templários e dos Hospitalários. De seu lado, os historiadores da arte, de formação, têm raramente desenvolvido pesquisas contínuas sobre as pinturas decorativas das capelas templárias e hospitalárias. Gaetano Curzi constitui uma das felizes exceções, mesmo se sua síntese sobre o Templo repousa sobre um corpus provisório e sobre estudos ainda muito fragmentários. Isso oferece, não menos, um precioso balanço das principais pinturas decorativas conhecidas até hoje, essencialmente para o espaço francês e, em menor medida, para a Itália e o Norte da Espanha. Todavia, se Curzi pôde se apoiar sobre alguns raros trabalhos atribuídos a verdadeiros conhecedores das ordens militares, seu livro não permanece menos tributário de monografias, de fato indispensáveis, a uma primeira abordagem, mas, frequentemente, datadas.

É necessário, de fato, evocar a tradição erudita, mais oriunda da história da arte, que se interessou sobre as pinturas decorativas nas comendadorias, sem que seus autores fossem necessariamente especialistas das ordens militares. Estas pesquisas, numerosas, mas difíceis de contabilizar, são essencialmente traduzidas por monografias dedicadas aos conjuntos pictóricos, ao mesmo tempo de sua redescoberta nos diversos lugares de culto há muito tempo abandonados. Seria 
instrutivo deter-se sobre as condições atuais destas pinturas medievais esquecidas sob as camadas de tintura da época moderna. As descobertas ocorridas a partir do século XIX, que se remetem aos tempos dos pioneiros da história da arte, revelam também as dificuldades particulares da intervenção sobre os monumentos situados no domínio privado. Assim, as decorações da capela de Montbellet (Saône-et-Loire) foram redescobertas durante a primeira guerra mundial (JEANTON, 1916-1917, p. 78-80), aquelas de Lavaufranche (Creuse) em 1958 (GUY, 1969-1962), aquelas de Notre-Dame de Lugaut (com. Retjons, Landes) por volta de 1962 (THIBOUT, 1965), aquelas de La Croix-au-Bost (Creuse) no início dos anos 1980 (PIEL, 1985), aquelas de Chauliac (com. Le Broc, Puy-de-Dome) por volta de 1990. A situação dos antigos conjuntos conventuais, que tinham sido vendidos como bens nacionais durante a Revolução, explica, assim, a lentidão dos procedimentos de proteção e de restauração e os problemas de acesso aos conjuntos, frequentemente muito degradados. Até mesmo, às vezes, algumas pinturas foram dilapidadas para serem vendidas a antiquários e, como em Saint-Pierre de Campublic, em Gard (ALIQUOT, 1985, 268-273), quando não foram intencionalmente destruídas ao mesmo tempo que os edifícios que as continham (Artins, Épinassy, Metz)5. Nestas condições, pouco propícias, deve-se a membros de sociedades eruditas locais as primeiras reconstituições e os primeiros apontamentos sobre estes conjuntos pictóricos (JEANTON, 1916-1917, p. 79-80). Malgrado as deficiências de seu tempo, algumas reconstituições são muito preciosas, pois constituem os únicos testemunhos de pinturas desaparecidas desde então. No caso de Artins (Loir-et-Cher), por exemplo, não se possui mais que os desenhos efetuados por Gervais Launay antes da destruição da capela em 1875 (CARRAZ \& DEHOUX, 2016, p. 38).

Após esses estudos pioneiros, as fases de restaurações mais recentes ou mesmo de novas descobertas de decorações pictóricas permitiram aos especialistas reatualizar as descrições e de produzir interessantes reflexões sobre a função da imagem no interior daqueles lugares de culto (DAVY, 1999; JUIN \& MARTIN, 2003;

\footnotetext{
${ }^{5}$ Em Épinassy (Saône-et-Loire), os afrescos retirados a partir de 1927 incomodavam o proprietário que destruiu a capela três anos mais tarde (VAIVRE, 2006, p. 1038).
} 
CORTOT, 2005). Alguns autores propuseram interpretações simultâneas sobre o sentido dos programas pictóricos ligados aos Templários e aos Hospitalários. Mas aqueles raramente chegaram ao conhecimento de uma historiografia das ordens militares, frequentemente autoreferencial e, às vezes, fechada às publicações nãoanglófonas. Por exemplo, quem tem lido as hipóteses de Claude Andrault-Schmitt, formuladas a partir das pinturas templárias de Paulhac (Creuse), sobre a importância do culto da cruz e da sensibilidade ao martírio (ANDRAULT-SCHMITT, 2002)? Essas ideias aproximam-se, contudo, das observações formuladas por alguns historiadores das ordens militares a partir das fontes escritas. Por outro lado, com exceção de alguns autores que tomaram a tarefa de reunir documentação, o mundo das ordens militares permanece estrangeiro a maior parte dos historiadores da arte, aos quais escapam tanto o estatuto preciso dos lugares de culto que acolhiam os ornamentos quanto o contexto local e institucional nos quais o tema estava razoavelmente inscrito. Às vezes, não se evita alguns pressupostos errôneos sobre estas ordens, que seriam anedóticos se eles não arriscassem falsear a interpretação (GABORIT, 2002, p. 285; CORTOT, 2005, p. 155 e 162-163).

Algumas considerações sobre a função ritual da imagem têm sido formuladas para as ordens militares, mas é ainda bem prematuro apontar uma síntese. A frequência das cruzes de consagração pictóricas - identificadas, entre outros lugares, em Paulhac, La Croix-au-Bost, Lavaufranche ou Jalès - permitiu sugerir a importância dedicada pelos frades à sacralização de suas capelas. Mas, além do fato de que elas, à vezes, fossem vermelhas sobre fundo branco, a presença destas cruzes é original? A frequência das cruzes de consagração representadas nas capelas templárias poderia estar ligada a importância que os frades atribuíam ao aniversário da consagração de suas capelas (DAILLIEZ, 1972, p. 157, § 360). Entrementes, no estado atual do conhecimento, é impossível dizer se as ordens militares se distinguiam por práticas litúrgicas específicas e quais eram suas repercussões sobre a organização dos ornamentos pictóricos. Os trabalhos de Cristina Dondi mostraram simplesmente que os Templários, mais que os Hospitalários, se conformavam aos 
costumes das dioceses nas quais suas comendadorias eram implantadas (DONDI, 1994 e 2010).

O mesmo vale para as devoções que a escolha dos temas e dos santos representados nas capelas é supostamente o reflexo. Há diferenças, na ordem da espiritualidade, entre Templários e Hospitalários? Tom Licence esboçou algumas hipóteses a partir das fontes escritas: os Hospitalários teriam sido menos direcionados para a adoração do Cristo sofredor e puderam se abrir a outros modelos hagiográficos diferentes daquele da "santa cavalaria” encarnada pelos Templários (LICENCE, 2005, p. 43-47 e p. 55-57). As pinturas, ou melhor, as outras imagensobjeto apresentadas em suas respectivas capelas, validariam estas impressões? No caso dos motivos puramente ornamentais (falsos aparatos, ornamentações geométricas ou vegetais), as capelas das ordens militares não parecem ser particularmente distintas de outros lugares de culto (MIGUET, 1995, p. 93-94).

\section{As ornamentações pictóricas conservadas em França: breve estado dos lugares}

A partir da bibliografia conhecida por mim e de algumas sondagens sobre a internet, eu tenho identificado quase uma quarentena de capelas conservando, atualmente, vestígios datáveis entre a metade do século XII e início do XIV. Este apanhado impôs algumas observações prévias que relevam da precaução epistemológica.

1. De início, sobre a distribuição geográfica das ornamentações identificadas: aquela se deve seja a razões históricas seja às condições da pesquisa. Assim, a densidade da implantação das comendadorias no sudoeste explica que este espaço conserve numerosos traços de ornamentações. Mas, a Aquitânia foi igualmente animada por um grande dinamismo artístico e suscitou uma verdadeira tradição regional de igrejas ornamentadas com pinturas (GABORIT, 2002). As igrejas do sudoeste 
têm, portanto, desde longa data, atraído o interesse dos historiadores da arte que se dedicaram, notadamente, a inventários regionais. Na Gironda, no Poitou-Charente e até no Limousin tem-se, então, oferecido condições favoráveis à realização e à boa conservação de conjuntos pictóricos nas capelas das comendadorias, o que frequentemente não tem sido o caso de outras regiões.

2. O outro destaque concerne à atribuição das decorações: mais de dois terços dos sítios são associados ao Templo, o terço restante somente releva do Hospital antes de 1314 (data na qual a maior parte das comendadorias templárias tem sido entregues aos Hospitalários). Esta superrepresentação do Templo não reflete forçosamente uma realidade histórica; ela se deve simplesmente a um desequilíbrio historiográfico em detrimento do Hospital e pelo fato que os Templários sempre atraíram mais a atenção.

3. Enfim, esta cifra de uma quarentena de decorações elencadas não se reveste de qualquer significado absoluto. De início, por que este inventário é muito provisório: muitos sítios escapam, sem dúvida, a meu conhecimento, tanto que outros traços pictóricos permanecem, provavelmente, a descobrir sob os revestimentos posteriores. Em seguida, por que a maior parte das decorações pictóricas medievais desapareceram efetivamente sob os revestimentos, sob o efeito das deteriorações e destruições. Na Idade Média, os interiores das igrejas eram quase sempre revestidos por ornamentos pictóricos e as capelas das ordens militares não faziam exceção.

Malgrado sua característica provisória e díspar, este corpus não minimiza a possibilidade de elaboração de um quadro de reflexão geral. Detemo-nos, inicialmente, sobre as questões de cronologia. Os mais antigos traços conservados não parecem anteriores a meados do século XII e eles nos são frequentemente vindos 
em um estado assaz degradado. Os vestígios subsistentes da semicúpula da capela templária de Jalès (Ardèche) estão, talvez, entre os mais antigos; se tornou impossível distinguir aí a mandorla no fundo azul, outrora destacada por Robert Saint-Jean (1987, p, 26). Entretanto, os arabescos estilizados, sublinhando o intradorso do arco e a cornicha, são mais visíveis (alguns foram provavelmente repintados na época moderna). A segunda metade do século XII oferece essencialmente decorações ornamentadas: encontra-se uma grande variedade de motivos geométricos, mas as decorações cobrindo por excelência são constituídas de peças falsas que os especialistas preferem melhor chamar de "representação de pedras talhadas". De fato, este tipo de aparato pintado tem um valor superior ao da pedra talhada aparente, no sentido em que contribui para magnificar a sacralidade do edifício. O falso aparato pintado está presente em todos os lugares, como em Villemoison (Nièvre), onde aquele remonta ao fim do século XII. As decorações figuradas ou historiadas interviriam em uma segunda fase cronológica, isto é, não antes do último terço do século XII, segundo o estado do que tem sido conservado. A superposição das decorações figuradas sobre as peças pintadas se verifica, às vezes, como em Auzon (Vienne), onde as peças falsas, atribuíveis a duas fazes diferentes, se intercalam entre duas outras fases de motivos decorativos e de decorações figuradas (BELLIN, 2000) [Figura o1]. Enfim, se encontra ainda exemplos de representações simbólicas, simplesmente tratadas com ocre, como em Saint-Genisdu-Bois (Gironde) ou em Montsaunès que são dois exemplos templários ${ }^{6}$. ${ }^{6}$ A associação entre estas representações simbólicas e os Templários é frequentemente propícia a especulações esotéricas e a outros
delírios templaristas sobre os quais é inútil se deter aqui. 
Figura o1: Auzon (Vienne), capela do Templo, semicúpula do coro:

detalhe do falso aparato ornamentado recoberto pelo Tétramorfo.

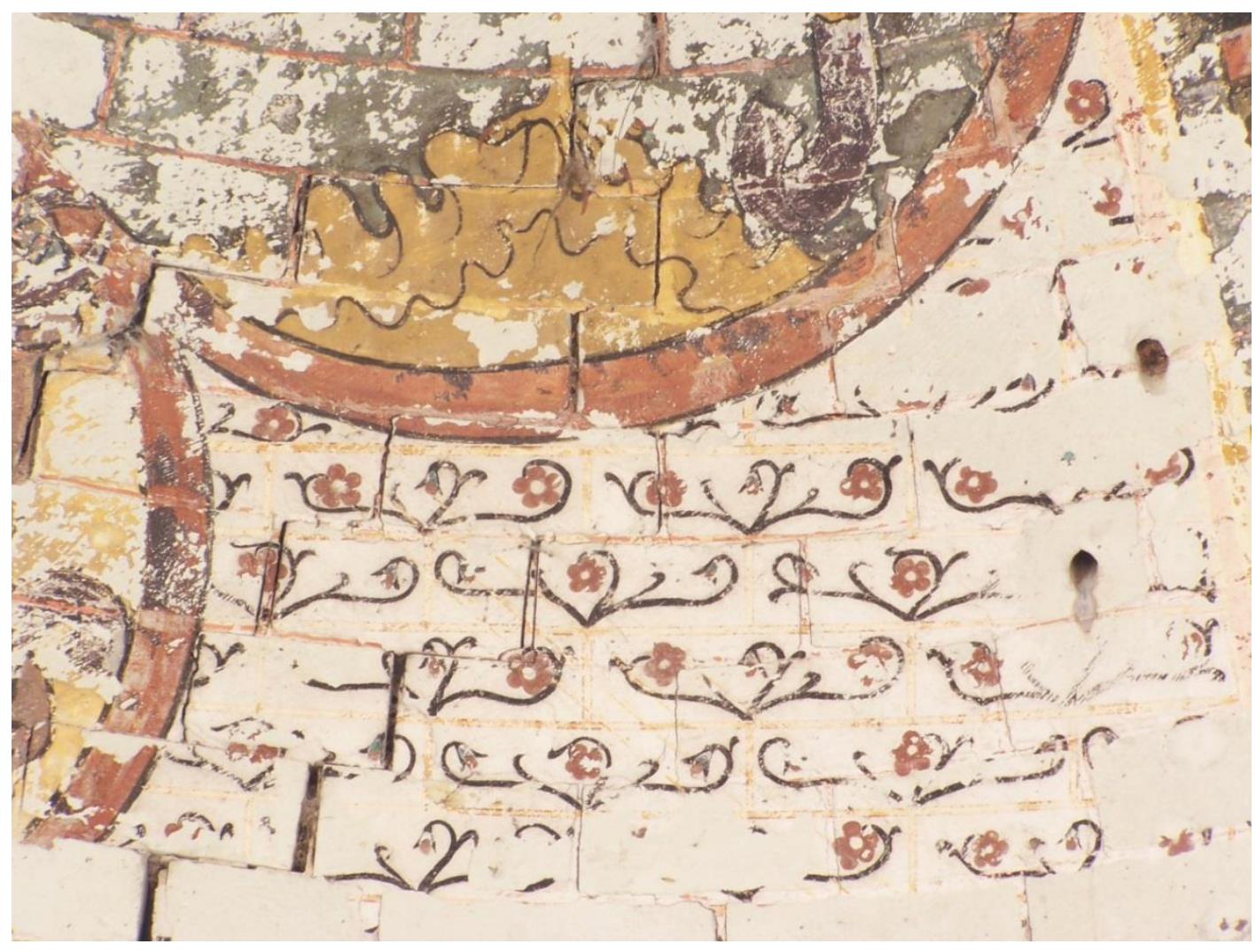

Fonte: (C) cliché J.-F. Lavrard.

Se se acredita nas datações propostas pelos estudos consagrados a estas diferentes capelas, um número não negligenciável de realizações deve ser situado no último quarto do século XIII (Paulhac, La Croix-au-Bost, Lavaufranche, Ruou no Var), algumas vezes, no início do século seguinte (Montbellet, Auzon). Uma tal cronologia, sobretudo quando ela é aplicada a programas notáveis, é suficiente para contradizer a visão de declínio, ainda difundida, de Hospitalários e, principalmente, de Templários, diante do grande número de críticas e do desencorajamento face a situação preocupante da Terra Santa. A sucessão das campanhas de decoração ainda necessitariam ser melhor relacionadas com seu quadro momentâneo, com as eventuais transformações da arquitetura, com as disposições litúrgicas ou com a 
evolução das devoções no seio de uma mesma comunidade. De maneira geral, é frequentemente na esteira de uma construção nova que os frades empreenderam decorar todo o edifício ou uma parte deste (Paulhac, Montbellet, Plaincourault). Mas, há também o caso dos edifícios herdados. Em Saint-Pierre de Campublic, sem dúvida, pouco depois de terem tomado possessão desta igreja rural, em 1193, e de terem engrandecido o coro, os Templários fizeram realizar um Cristo em Glória, cuja elaboração imita deliberadamente uma estética arcaizante, por exemplo, no tipo de mandorla em forma de oito (CARRAZ \& DEHOUX, p. 54-56) [Figura o2]. Quando os frades se instalaram nesta capela que relevava de um domínio da igreja de Arles, atestado desde a época carolíngia, a decoração pictórica se remetia a apropriação de um lugar antigo venerado. Ao mesmo tempo, a escolha de representar aqui os apóstolos Pedro e João e a Virgem, isto é, os santos dedicados aos atuares primitivos, mostra que os frades desejaram inscrever sua presença na herança local. Para uma outra fase da história das ordens e que extrapola nosso quadro cronológico, a transferência de certas comendadorias do Templo ao Hospital teve frequente incidência sobre as decorações quando os Hospitalários decidiram imprimir sua marca nas capelas que eles tinham herdado. Em Montsaunès (Haute-Garonne), um segundo programa do século XIV vem se inserir no primeiro conjunto, talvez inacabado, da época templária. Profetas e apóstolos, representados em um estilo assaz maneirista, já gotizante, tomou lugar, sob as arcadas de um falso trifório onde três bispos, cuja realização é ainda de espírito românico, estavam dispostos no tempo dos Templários (BOUVIER, 2004, p. 173-180). 
Figura o2. Saint-Pierre-de-Campublic (Gard), capela do Templo: abside do coro e absidiola sul.

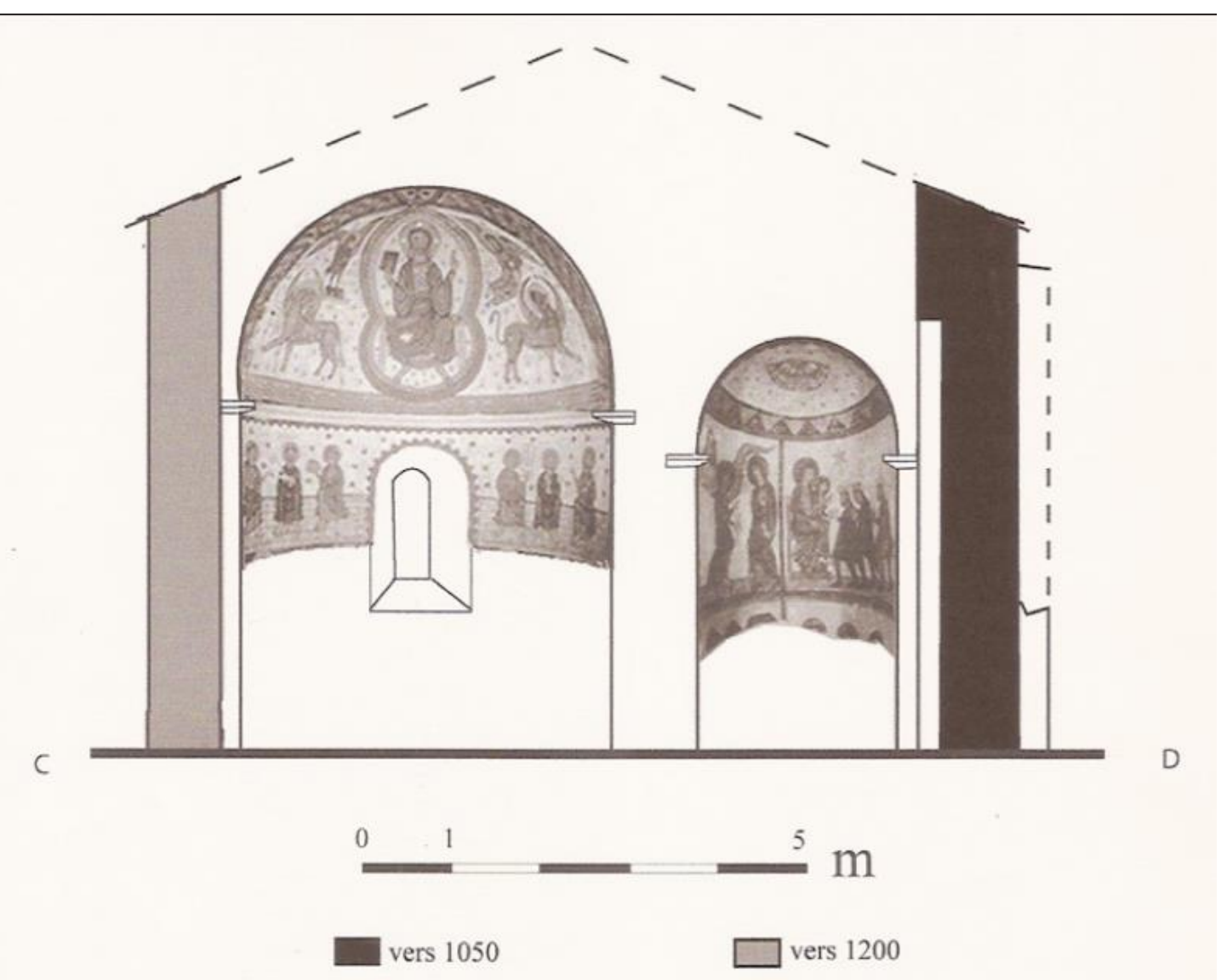

Fonte: (C) Coupe André Michelozzi (com autorização de Arlette Michelozzi).

Seria necessário considerar, também, a própria história de cada estabelecimento, as relações da comunidade com a aristocracia local ou bem com o episcopado, para tentar compreender e datar a sucessão das decorações dentro de um mesmo edifício. Aliás, trata-se de uma meta bem teórica, pois as fontes escritas dificilmente estão em condições de fornecer um esclarecimento tão preciso. De fato, por um acaso infeliz, as mais belas capelas ornamentadas relevam de comendadorias que praticamente não conservaram fontes próprias7. Assim, os Hospitalários

\footnotetext{
${ }^{7}$ No caso de Montbellet, por exemplo, os arquivos da época templária, que existiam ainda no século XVIII, desapareceram em seguida (JEANTON, 1916-1917, p. 74).
} 
deveram sua implantação, em Lugaut, ao patrocínio do poderoso Amanieu V d'Albret $\left(\dagger_{1240)}\right.$ que tinha dado à ordem esta igreja com seus dízimos. Malgrado a importância da linhagem d'Albret, os arquivos, não documentando, todavia, a chegada dos frades e o patrocínio de Armanieu V, não deixaram outro traço escrito que a inscrição sobre a cena de doação figurada no muro sul da capela (FAVREAU, 1981, p. 102-104) [Figura o3].

Figura o3. Lugaut (com. Retjons, Landes), capela do Hospital. Muro norte, de alto a baixo: chegada de Amanieu d'Albret e de seu séquito / doação da igreja ao comendador do Hospital / Concordia e Obediência.

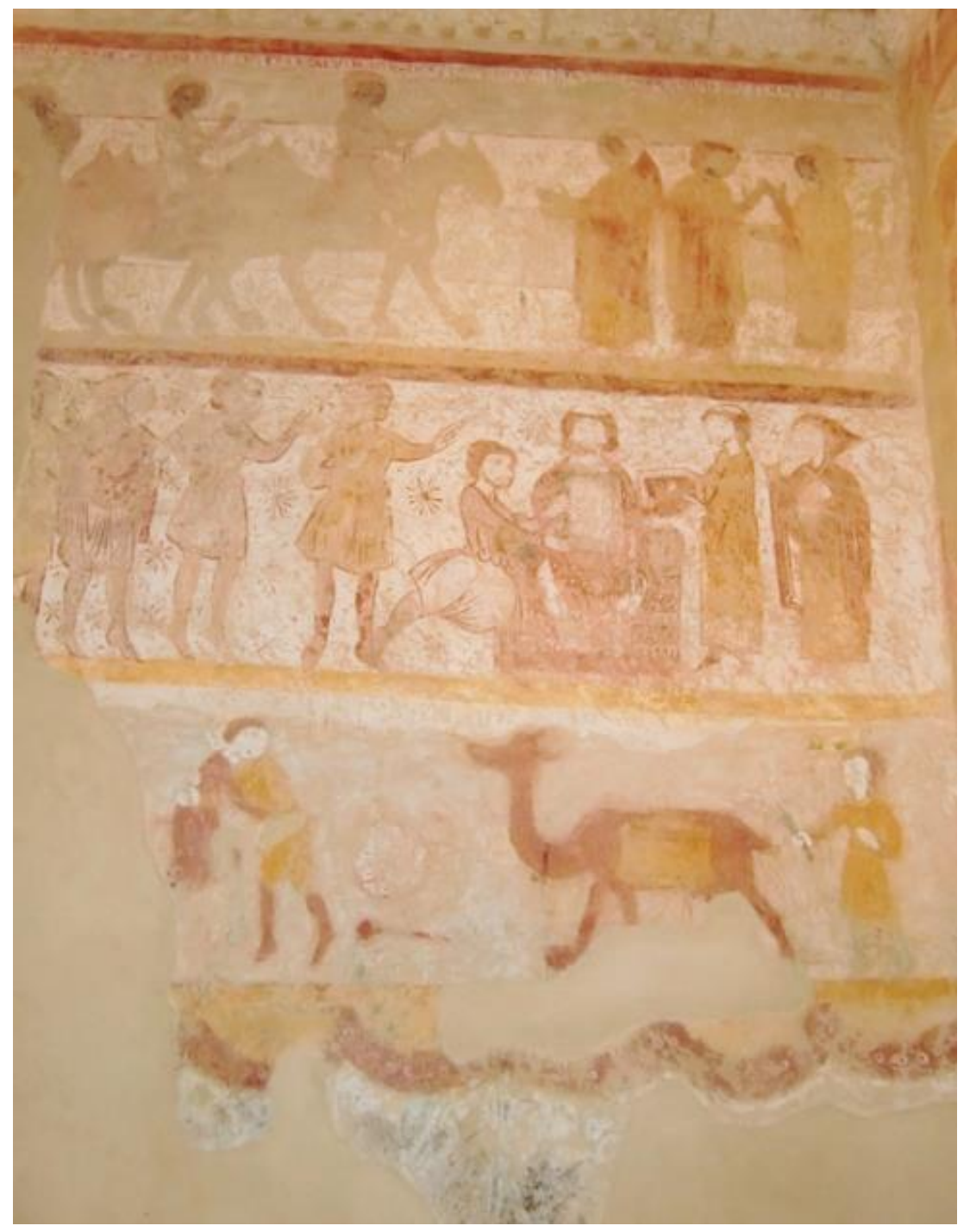

Fonte: (C) cliché D. Carraz. 


\section{Santos e cavaleiros: breve levantamento das decorações figuradas}

A maior parte das decorações conservadas hoje em dia se concentram nos coros dos edifícios eclesiásticos. É necessário, entretanto, insistir sobre a ambição de alguns programas concebidos de maneira distinta a escala de todo o edifício, como em Paulhac ou em Montbellet. Malgrado a degradação irremediável de muitos conjuntos, pode-se ainda imaginar a profusão de cores que devia impressionar os visitantes que entravam nestes espaços sagrados. É, de fato, atestado que algumas capelas eram inteiramente recobertas por revestimentos pictóricos, até o intradorso das abóbadas, sublinhado por falsos arcos em chave como em Plaincourault, na diocese de Poitiers (JUIN \& MARTIN, 2003). Evocou-se, anteriormente, a importância da pintura ornamental. É necessário bem dizer, de fato, que a maior parte das capelas das ordens militares, que eram edifícios modestos, receberam este tipo de decoração, cuja realização demandava menos talento que os temas figurativos. O revestimento das superfícies murais encontra ainda uma outra razão ligada a arquitetura. Em muitas capelas, templárias e hospitalárias, a definição dos espaços, dentro dos edifícios, as grandes articulações entre o coro e a nave, eram sublinhadas mais por ornamentações pictóricas que pelos elementos arquiteturais, tais como as colunas. Aquilo é notadamente característico na Aquitânia e no Limousin, onde a nave única e a modéstia das aberturas, como dos suportes, oferecia vastas superfícies murais para a disposição da pintura (Plaincourault, Paulhac) [Figura 4]. 
Figura 04. Paulhac (Creuse), capela do Templo. Muro norte, quarto portal: da esquerda para direita : martírio de São Simão / decaptação de São João Batista / Crucificação de São Pedro.

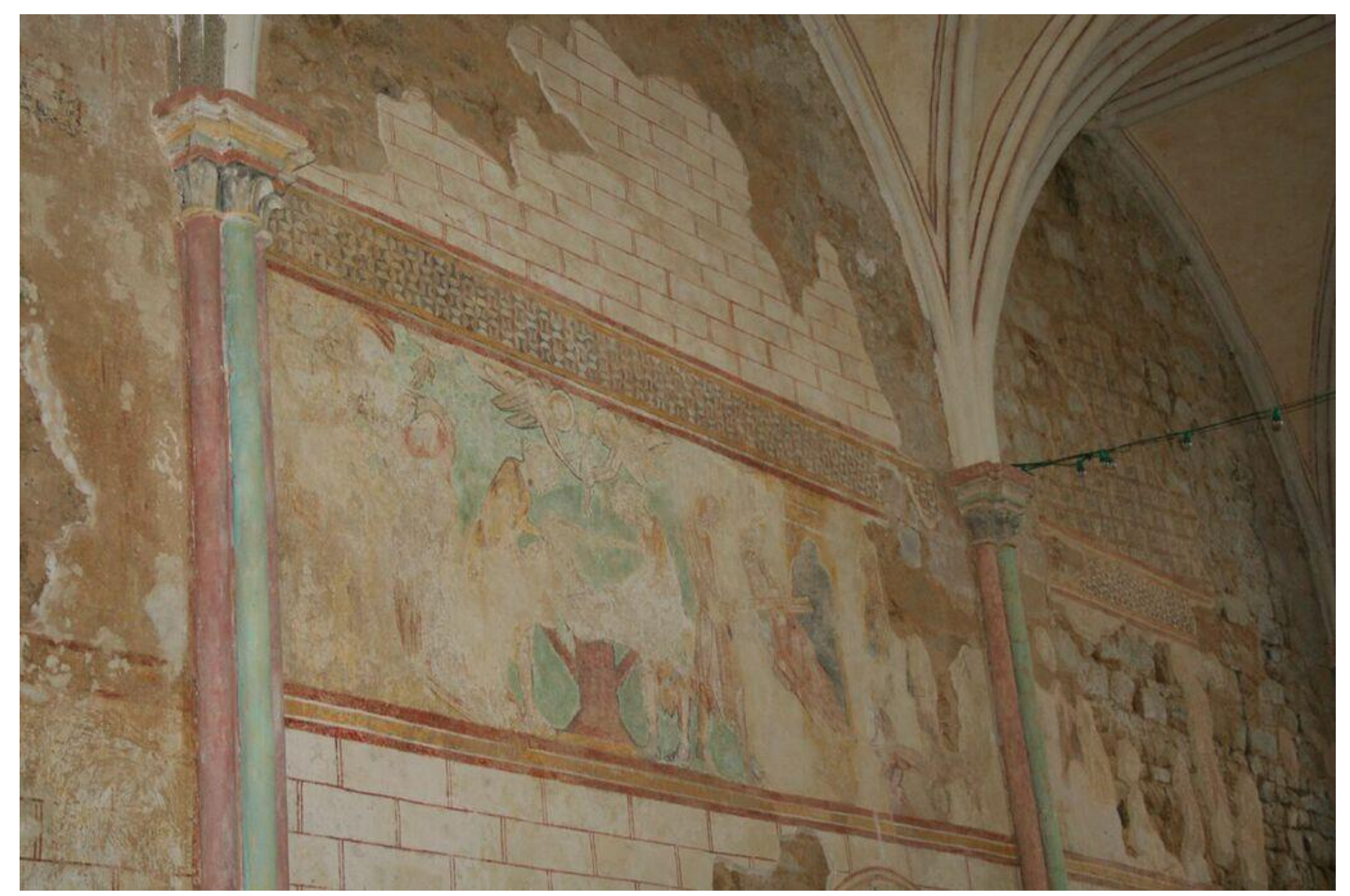

Fonte: (C) cliché Cécile Voyer.

Quais são as representações figurativas e historiadas dessas pinturas? É impossível, em algumas linhas, fazer um panorama pelos principais temas presentes nas capelas das comendadorias. A síntese de Gaetano Curzi tem, por outro lado, dado uma visão do conjunto dos assuntos privilegiados pelos Templários (CURZI, 2002). De modo clássico, as semicúpulas das extremidades dos coros, acolhem as grandes representações ligadas ao triunfo do Cristo: o Cristo em Glória acompanhado do Tetramorfo aparece mais frequentemente, como em Villemoison ou em Plaincourault. A Crucificação é uma outra imagem presente nos coros, como em Ambarès-Lagrave (Gironde) e em Lavaufranche. Após o Cristo, não é surpreendente a importância dada a figura marial, através do Coroamento (Ruou), da Anunciação (Coulommiers em Seine-et-Marne) e sobretudo a Virgem com a Criança (Paulhac, 
Plaincourault, Ambarès-Lagrave...). Este enunciado muito rápido tem por único objetivo lembrar a devoção que as duas ordens votavam, às vezes, ao Cristo-rei e ao Cristo sofredor, assim como a Virgem. Mas aquilo é verdadeiramente original? A ligação com a figura dos apóstolos é pouco mais original, como se encontra aqueles em posição de cruciferários, como em La Croix-au-Bost ou ligados aos profetas do Antigo Testamento como em Montsaunès.

Enfim, pode-se apontar a população do sanctoral ligada aos Templários e aos Hospitalários. Formulamos, somente de passagem, três destaques que constituem pistas para se seguir:

- a predileção dos Templários por figuras de martírio, bem destacada por Claude Andrault-Schmitt a partir do caso de Paulhac, oferece, de fato, um verdadeiro martirológio (ANDRAULT-SCHMITT, 2002) [Figura 04]. Este interesse pelo martírio esteve relacionando com a vocação guerreira dos frades e com a consciência que eles tinham de verter sangue para a defesa da cristandade.

- o interesse pela santidade feminina, notadamente por santa Catarina, cuja imagem é muito presente nos arredores das comendadorias (Paulhac, Lavaufranche, Montbellet...). Destaca-se, por outro lado, a proximidade dos Hospitalários com certos aspectos da santidade feminina (NICHOLSON, 2002 \& 2005), tanto que a devoção à Santa Catarina se explica também pela origem oriental e pela característica militante desta figura santa.

- enfim, na origem da publicação coletiva sobre a cultura visual das ordens militares (CARRAZ \& DEHOUX, 2016), mencionada na introdução, se encontra uma interrogação sobre a devoção particular que os frades teriam podido manifestar pelos santos guerreiro. Algumas figuras marciais aparecem, de fato, nas capelas: as mais célebres, São Miguel e São Jorge, são representadas em lugares como Cressac (Charente), Montsaunès e Coulommiers. Em compensação, é o estatuo episcopal, não aquele do soldado, que é escolhido para São Martim em Montsaunès. Em definitivo, os guerreiros celestes, como Jorge ou Miguel, não parecem ter estado 
muito mais presentes nas capelas das ordens militares quanto nas igrejas dependentes de outras instituições. Esther Dehoux já propôs algumas hipóteses para explicar esta discrição (DEHOUX, 2014, p. 188-194). Assim, o gregoriano São Jorge teria muito radicalmente encarnado a ruptura entre clérigos e laicos para corresponder ao "ideal híbrido do monge soldado" e de seus benfeitores aristocráticos. Por outro lado, o Capadócio era muito associado a ideia de cruzada para que os cronistas se privassem de assimilar os Templários em combate a este santo guerreiro e que os frades não lhe dirigissem suas preces em diversas circunstâncias. Este exemplo lembra que os laços entre iconografia e testemunhos escritos são sempre delicados para se estabelecer.

Desde Paul Deschamps, há um considerável interesse pelas cenas de batalhas e de cruzada pintadas nas igrejas (DESCHAMPS, 1947). Como se poderia esperar, igualmente encontra-se tais representações nas capelas das comendadorias. E não se pode evitar aqui de lembrar o caso célebre, mas complexo, de Cressac: duas cenas de batalha, correspondendo a diferentes fases da decoração, se sobrepondo no muro norte (DAVY, 1999). O registro superior, ilustrando uma carga de cruzada, é muito conhecido. Alguns eruditos reconheceram a batalha de La Boquée, em 1163, outros, a vitória alcançada contra Karboga em 1098. Mas poderia também se tratar de uma evocação "genérica” do combate contra os infiéis na Terra Santa. Tais imagens, que reenviam claramente à vocação das ordens militares, são habitualmente apresentadas como uma sorte de "propaganda" em favor da missão, de fato, do sacrífico, dos frades no Oriente ${ }^{8}$. Aquilo faz sentido, mas ainda é necessário precisar a quem tais imagens eram destinadas. Por outro lado, a identificação dos cavaleiros representados é geralmente problemática, pois frequentemente é difícil determinar se se trata de frades ou de cruzados. Enfim, assim como o tem feito notar Claude Andrault-Schmitt, estas representações guerreiras amiúde aparecem como

${ }^{8}$ Sobre a ideia de "propaganda visual" em favor da cruzada, consultar: Morris (1998). 
secundárias junto aos programas pictóricos (ANDRAULT-SCHMITT, 2002, p.138139).

Outros gêneros de cenas "profanas" podem suscitar problemas de interpretação. O muro norte da capela hospitalária de Lugaut oferece um ciclo cuja mensagem se integra perfeitamente bem no conjunto do programa: a Luxúria e a Discórdia se situam bem sob a representação do Inferno, tanto que a Obediência e Concórdia estão encimadas pela cena da doação de Amanieu d'Albret que foi evocada mais cedo [Figura o3]. Para Jean-Pierre Suau, "estes valores morais se dirigem, prioritariamente, aos simples laicos: sem dúvida, os fiéis da paroquia de Lugaut, para quem este conjunto pictórico também era destinado" (SUAU, 1993, p. 286). Tais esboços, inspirados na vida quotidiana (o jogo, a sedução, os conflitos) podiam certamente visar laicos illiterati. Entretanto, a advertência contra o pecado da carne e a violência gratuita, de um lado, o elogio da humildade e da obediência, de outro, lembravam principalmente aos frades Hospitalários, sendo a maioria oriunda da pequena aristocracia, que eles estavam engajados a romper com o habitus inerente a seu grupo social. De fato, se a violência inútil é figurada por um armamento tomado aos plebeus e aos muçulmanos (massa, escudo redondo); já o combatente que triunfa sobre o mal, incarnado pelo leão na lateral da janela, é claramente representado como um cavaleiro. Me parece que a distinção entre estas duas formas de combate, um perigoso para alma e o outro santificador, se dirigem então, a princípio, aos bellatores.

\section{A escolha das decorações e os comanditários}

Questionar o sentido destas imagens pictóricas implica então interrogar melhor sobre o estatuto dos lugares de cultuo que lhes têm acolhido. Não é sempre fácil discernir isso, na ausência de fontes, mas lembremos que, em teoria, é necessário distinguir capelas conventuais, que eram abertas somente aos frades, aos familiares e aos benfeitores mais próximos, as igrejas paroquiais, cujas ordens somente tinham o patronato, e, enfim, os lugares de culto com estatuto 'misto', isto 
é, integrados nas comendadorias e que permaneciam abertos aos paroquianos. A escolha das decorações podia depender das diferentes funções destes "lugares rituais" e do estatuto das personagens que os frequentavam9. De maneira geral, os frades se esforçaram por abrir o mais amplamente possível suas capelas aos fiéis, deixando surgir conflitos com clero paroquial. Muitas fontes nos informam, por exemplo, que os fiéis se espremiam em certas capelas do Templo nos momentos maiores do ciclo litúrgico, como no momento da Adoração da Cruz (SCHENK, 2012, p. 216-219). O mesmo pode valer para os cultos locais. A escolha de fazer figurar imagens de santos regionais seria a marca de devoções partilhadas entre os frades e seu círculo imediato (bispos, benfeitores, fiéis). Encontra-se, assim, Santa Valéria associada a São Marcial, apóstolo do Limousin, em Lavaufranche e em Paulhac. Santa Radegonda, rainha merovíngia e fundadora do mosteiro Sante-Croix de Poitiers, era representada em Auzon. Enfim, sobre o muro norte da igreja de Montsaunès, São Bernardo de Comminges (†1123) estava, em conformidade com uma passagem de sua vita, associado a São Martim. A presença deste santo bispo, oriundo da linhagem dos condes de Comminges, manifesta bem claramente os laços estreitos que uniam esta família à comendadoria de Montsaunès (HIGOUNET, 1957, p. 220-221).

Se o santoral é representado em toda sua diversidade nas capelas dos frades, buscar-se-ia em vão individualidades mais estreitamente ligadas às ordens do Templo e do Hospital. Não existe iconografia própria ou "pensamento figurativo", junto aos Templários ou aos Hospitalários, comparável àquela que os Franciscanos e os Dominicanos desenvolveram em torno da pessoa de seu fundador ou de outros santos saídos de suas ordens (DONADIEU-RIGAUT, 2005). A ausência de uma iconografia identitária se explica, sem dúvida, pelo fato de que os Templários nunca promoveram o culto de Hugues de Payns. A figura de São Geraldo foi mais cultuada pelos Hospitalários, mas o imaginário deste fundador se desenvolveu tardiamente. Por outro lado, contrariamente aos modelos femininos de santidade no círculo dos

\footnotetext{
9 Éric Palazzo chamou a « déveloper les recherches sur l'iconographie des peintures muraes dans leurs relattions avec la typologie des
} édifices » (PALAZZO, 2005, p. 61). 
Hospitalários, os Templários não procuraram verdadeiramente promover santos saídos de suas linhas. Estes últimos jamais esqueceram o patronato de São Bernardo e o retábulo, datado do final do século XII, que ornava o altar de sua capela em Palma de Mallorca, é uma manifestação explícita disso (SALVADO, 2006). Mas, esta imagem, que liga a espiritualidade templária a São Bernardo, está isolada no estado atual do conhecimento.

A escolha das imagens se remete, finalmente, à questão dos comanditários, que é excepcionalmente colocada pelas monografias, a título apenas de hipótese. Haveria, nas igrejas conventuais, espaços ou monumentos privados reservados a familiares benfeitores ou a insignes dignitários (capelas, jazigos). A escolha dos ornamentos relevava, neste caso, do comanditário privado, como para o jazigo da linhagem de Toulouse, erigido contra o muro norte que sustenta a calha da igreja dos Hospitalários de Toulouse (MACE \& POUSTHOMIS-DALLE, 2009). Este exemplo toulousain se mostraria ainda mais excepcional, pois verdadeiramente não se conhecia demandas efetuadas a título privado nos arredores das comendadorias antes do fim da Idade Média. Novas descobertas (como os ornamentos da Maison des Dames de la Foi em Périgueux) ou a reconsideração dos antigos dossiês (como os afrescos da Tour Ferrande em Pernes-les-Fontaines) deveriam, todavia, conduzir a reavaliar a importância da demanda privada ligada às ordens militares desde o século XIII (CARRAZ, \& DEHOUX, 2016, p. 49-53).

Entretanto, é necessário vislumbrar, sobretudo, as demandas ligadas a parte comunitária da igreja, destinada aos frades e eventualmente aos fiéis. A qualidade das realizações, onde se distinguem o talento dos artistas, a utilização de pigmentos preciosos e de técnicas inovadoras, frequentemente foram destacadas. As pinturas de Paulhac apresentam uma rica paleta de cores e de técnicas de incisão e de incrustação (douramentos, pastas de vidro). $\mathrm{O}$ atelier que trabalhou em Plaincourault associou as técnicas do afresco e da têmpera, tanto quanto em Montbellet, o estabelecimento dos desenhos preparatórios foi particularmente cuidadoso. Algumas execuções estiveram relacionadas a objetos de ourivesaria, 
como a Virgem com a criança de Paulhac ou as cruzes de Montsaunès ou de Montbellet, próximas a algumas cruzes estaurotecas (CURZI, 2002, p. 37-38 e 111). Outras iniciativas foram empreendidas através das artes do vitral (Montbellet) ou da iluminura (cruz da Croix-au-Bost, Crucificação de Lavaufranche). Além disso, muitas observações têm revelado influências "bizantinizantes", aparentes seja no tratamento das imagens (Saint-Pierre de Campublic, Lugaut), seja nas escolhas temáticas, como em Ambarès-Lagrave ou ainda em Lugaut (GABORIT, 2002, p. 172174 e 277-285). Recentes reflexões mostram que as duas ordens, notadamente os Templários, tinham tomado múltiplas referências estéticas e semânticas da arte bizantina (SALVADO, 2010, p. 199-190). Algumas capelas, através das relíquias, dos objetos sagrados e das imagens que elas continham, ofereciam uma espécie de transposição da Terra Santa.

Quem decidia então a escolha das imagens e dos artistas? Em Montbellet, Hugues Cortot nega toda escolha aos Templários e prefere ver o patronato de uma poderosa linhagem vizinha, mas sem qualquer pista documental (CORTOT, 2005, p. 162-165). Em Paulhac, ou melhor, em Lugaut, a semântica de algumas imagens sugere mais a intervenção de alguns personagens vinculados à teologia (ANDRAULT-SCHMITT, 2002; GABORIT, 2005, p. 277-285), tanto que as abobadas de Montsaunès (quarto portal) se remetem, talvez, a especulações cosmográficas eruditas (BOUVIER, 2004, p. 154-162). Mas tudo aquilo não exclui que os Templários e os Hospitalários tenham sido menos capazes que outros religiosos para determinar os ornamentos de suas capelas e de contratar artistas. Desde o século XIII, pelo menos, influentes dignitários tinham a envergadura para impulsionar importantes realizações arquiteturais ou para fazer demandas de objetos de ourivesaria ou de livros iluminados (CARRAZ, 2016). Por que seria diferente para as pinturas que ornavam suas comendadorias? Mais ainda, as ordens militares tinham os meios para suas ambições artísticas. Em muitas comendadorias da França atual, o último terço do século XIII foi marcado por importantes canteiros de reconstrução à moda gótica. É bem possível que estas ordens religiosas pudessem também financiar ambiciosos programas pictóricos. Se é necessário, eu creio, 
reavaliar a iniciativa dos frades na ornamentação de suas capelas, as provas faltam, entretanto, para uma época como os séculos XII-XIII, que deixou sem atribuição a maior parte das demandas e das realizações artísticas.

Tem-se proposto aqui um rápido panorama da riqueza dos ornamentos pictóricos ainda visíveis nas capelas templárias e hospitalárias a escala de uma França atual, mas frequentemente reduzido, na prática, ao sudoeste aquitano e à Borgonha. Atualmente, arqueólogos e historiadores sabem bem que, majoritariamente, os muros, em pedra aparente hoje em dia, apontam lugares de culto que não correspondem em nada à cultura visual da Idade média. Se as superfícies murais eram bem revestidas e decoradas, se concentrar somente sobre as imagens pictóricas pode dar uma impressão parcial da realidade. De fato, é bom lembrar que os ornamentos pictóricos, "réseaux d’images”, não estariam dissociados de seu arredor arquitetural e escultórico ${ }^{10}$. Logo, para um dado edifício, é a globalidade das estruturas que é necessário considerar, a articulação dos diferentes espaços, em plano e em elevação, às ornamentações esculpidas. Mais ainda, o estudo de uma ornamentação pictórica deve, tanto quanto possível, ter em consideração outros artefatos frequentemente desaparecidos ou profundamente retrabalhados como as instalações litúrgicas - coros, armários, pias - e o mobiliário ${ }^{11}$. Sobre este último ponto, os inventários mobiliários dão uma ideia da riqueza dos ornamentos litúrgicos e das ornamentações nas celas das ordens militares. Bem numerosos a partir do início do século XIV e completados pelas visitas da ordem de Malta para a época moderna, estes inventários começaram a ser explorados, mas ainda têm muito a nos ensinar. Citemos, para terminar, o inventário, realizado em 1306, dos ornamentos da igreja hospitalária Saint-Jean d'Aix-en-Provence: além da quantidade de objetos litúrgicos preciosos, se encontra aí, de maneira especial, quatro imagens em prata, uma imagem da virgem em marfim sobre um tabernáculo, um outro tabernáculo precioso com imagens em marfim, telas da Virgem e de Santa Catarina. Enfim, a ausência dos paramentos, atualmente, está longe da atmosfera do

\footnotetext{
${ }^{10}$ Sobre a noção de "réseau d'images": ver Cécile Voyer (2010).

${ }^{11}$ Sobre a interação entre as diferentes imagens e os objetos de uma igreja na execução da liturgia: Éric Palazzo (2010, p. 39).
} 
século XIII, pois vinte e oito escudos, assim como um grande mural decorativo de uma cena cavaleiresca estavam dispostos nos muros (DELAVILLE LE ROULX, 1906, nº 4708). Estes escudos suspensos que, segundo São Bernardo e Matthieu Paris, ornamentavam igualmente a casa do Templo de Jerusalém, remetiam-se claramente à função guerreira e à dimensão cavaleiresca dos frades. Sem dúvida, assim como nos mosteiros beneditinos, os ornamentos pictóricos e o mobiliário litúrgico magnificavam em acréscimo a sacralidade dos lugares de culto vinculados às comendadorias. Em 1309, diante de seus juízes, o mestre do Templo, Jacques de Molay, podia, então, se vangloriar de não conhecer qualquer outra ordem religiosa cujas capelas fossem dotadas de ornamentos tão suntuosos ${ }^{12 !}$

\section{REFERÊNCIAS}

AFONSO, Luís. A pintura mural das igrejas das ordens militares em torno de 1500. Primeiras impressões de uma abordagem iconográfica, In: FERREIRA FERNANDES, Isabel Cristina (dir.). As Ordens Militares e as Ordens de Cavalaria na Construção do Mundo Ocidental. Actas do IV Encontro sobre Ordens Militares, Palmela (30 de Janeiro-2 de Fevereiro 2002), Lisbonne: Município de Palmela/GEsOS, 2005. p. 899-915.

AGOSTINO, Laurent d'. Les commanderies des Templiers et des Hospitaliers en Auvergne: éléments pour une architecture. In: Histoire et archéologie de l'ordre militaire des Hospitaliers de Saint-Jean de Jérusalem. Saint-Étienne: Publications de l'Université de Saint-Étienne, 2004, p. 75-101.

ALIQUOT, Hervé. Peintures romanes et iconographie des saints dans la basse vallée du Rhône. In: Mémoires de l'Académie de Vaucluse, t. VI, 1985, p. 260-276.

ANDRAULT-SCHMITT, Claude. L'imitation des apôtres et le martyre au combat. Les aspirations des Templiers de Paulhac entre l'abandon de Jérusalem et la chute d'Acre (1244-1291). In: Guerre et paix dans l'Orient méditerranéen.(Méditerranées, $\mathrm{n}^{\circ}$ 29), Paris, 2002, p. 117-150.

BASCHET, Jérôme. Les images: des objets pour l'historien ?. In: LE GOFF, Jacques (dir.); LOBRICHON, Gui (dir.). Le Moyen âge aujourd'hui. Trois regards contemporains sur

\footnotetext{
12 « Quorum primum erat quod idem magister nesciebat aliquam aliam religionem in qua capelle et ecclesie religionis haberent meliora et pulchriora ornamenta et reliquias ad cultum divinum pertinencia et in quibus per presbiteros et clericos melius deservirent in divinis, exceptis ecclesiis cathedralibus » (LIZERAND 1923, p. 166).
} 
le Moyen âge: histoire, théologie, cinéma, (actes de la rencontre de Cerisy-la-Salle, juillet 1991). Paris: Le Léopard d'or,1998, p. 101-135.

BASCHET, Jérôme. L'iconographie médiévale. Paris: Gallimard, 2008.

BASCHET, Jérôme ; RIGAUX, Dominique. Le médiéviste et les images à l'ère de l'écran global. In: Être historien du Moyen Âge au XXI ${ }^{e}$ siècle. Paris: Publications de la Sorbonne, 2008, p. 259-272.

BELLIN, Philippe. Les peintures murales de la commanderie d'Auzon. In: Bulletin de la Société des Sciences de Châtellerault, $\mathrm{n}^{\circ} 81,2000$.

BOUVIER, Jean-François. Le programme iconographique de l'église SaintChristophe de Montsaunès, mémoire de maîtrise, Université de Toulouse-Le Mirail, 2004 .

BOYER, Jean-François \&NOTIN, Véronique. Contribution à l'étude du mobilier médiéval des églises ayant appartenu à l'ordre des Hospitaliers sur la Montagne limousine. In: Les ordres religieux au Moyen Âge en Limousin, Treignac: Éd. les Monédières, 2003, p. 195-229.

CARRAZ, Damien. Individualisation et maîtrise d'ouvrage. Autour de quelques dignitaires de l'Hôpital dans le Midi de la France (v. 1250-v. 1350). In: Revue d'histoire ecclésiastique, vol. 111.1-2, 2016, pp. 34-59.

CARRAZ, Damien. La redécouverte de deux châteaux de l'Hôpital en Haute- Provence: Manosque et Puimoisson exhumés par les sources écrites. In: BAUD, Anne ; POISSON, Jean-Michel (dir.). Le château de Belvoir et l'architecture fortifiée de l'Hôpital de Saint-Jean de Jérusalem, actes de la table-ronde de Lyon, Archives départementales du Rhône, 1er-2 décembre 2016, Lyon, Maison de l'Orient, à paraître.

CARRAZ, Damien \& ASPORD-MERCIER, Sophie. Le programme architectural d'un pôle seigneurial: la commanderie de Montfrin (Gard). In: MATTALIA, Yoan (dir.). Organiser l'enclos: sacré et topographie dans les maisons hospitalières et templières du Midi de la France.Actes du séminaire Terrae (Toulouse, 24 avril 2009), Archéologie du Midi médiéval, t. 28, 2010, p. 297-316.

CARRAZ, Damien (dir.); DEHOUX, Esther (dir.). Images et ornements autour des ordres militaires au Moyen Âge: culture visuelle et culte des saints (France, Espagne du Nord, Italie), Toulouse: Presses universitaires du Midi, 2016.

CORTOT, Hugues. Les décors peints dans la chapelle Sainte-Catherine de Montbellet: un exemple de peintures murales dans une fondation templière. In: RUSSO, Daniel (dir.), Peintures murales médiévales, $X I I^{e}-X V I^{e}$ siècles. Regards comparés, Dijon: Éditions universitaires de Dijon, 2005, p. 143-167.

CURZI, Gaetano. La pittura dei Templari. Milan: Silvana Editoriale, 2002. 
CZAJA, Roman(dir.); SARNOWSKY, Jürgen (dir.). Selbstbild und Selbstverständnis der geistlichen Ritterorden. (Ordines Militares - Colloquia Torunensia Historica, XIII), Torun, 2005.

CZERNIAK, Virginie. Les peintures murales des édifices non cultuels dans le Midi languedocien : état de la question. In: Le décor peint dans la demeure au Moyen Âge. Journée d'étude, Archives départementales de Maine-et-Loire, 15-16 novembre 2007. Disponível em : <http://expos.maine-et loire.fr/culture/peintures_murales/medias/pdf/virginie_czerniak.pdf $>$. Acesso em :

DAILLIEZ, Laurent. Les Templiers et les règles de l'ordre du Temple. Paris: Éd. Pierre Belfond, 1972.

DAVY, Christian. Les peintures murales romanes de la chapelle des Templiers de Cressac. In: Charente. Congrès archéologique de France, $153^{e}$ session (1995), Paris: Société française d'archéologie, 1999, p. 171-178.

DEHOUX, Esther. Saints guerriers. Georges, Guillaume, Maurice et Michel dans la France médiévale (XIe-XIII siècle). Rennes: Presses universitaires de Rennes, 2014.

DELAVILLE LE ROULX, Joseph. Cartulaire général de l'ordre des Hospitaliers de Saint-Jean-de-Jérusalem (1100-1310). Paris, 1906, t. IV.

DESCHAMPS, Paul. Combats de cavalerie et épisodes des croisades dans les peintures murales du XII e et du XIII e siècle. In: Miscellanea Guillaume de Jerphanion. (Orientalia Christiana Periodica, 13), Rome, 1947, p. 454-474.

DONADIEU-RIGAUT, Dominique. Penser en images les ordres religieux $\left(\mathrm{XII}^{\mathrm{e}}-\mathrm{XV} \mathrm{e}^{\mathrm{e}}\right.$ siècles). Paris: Editions Arguments, 2005.

DONDI, Cristina. Missale vetus ad usus Templariorum: l'ordine dei cavalieri templari in area modense nei secoli XII-XIV. In: Aevum, 68, 1994, p. 339-366.

DONDI, Cristina. Liturgies of the Military Religious Orders. In: LANG, Uwe M. (dir.),The Genius of the Roman Rite. Historical, Theological and Pastoral Perspectives on Catholic Liturgy, Chicago: Hillenbrand Books, 2010, p. 143-158.

ELM, Kaspar. Die Spiritualität der geistlichen Ritterorden des Mittelalters. Forschungsstand und Forschungsprobleme. In: "Militia Christi" e Crociata nei secoli XI-XIII. Atti della undecima settimana di studio di Mendola (1989). Milan: Vita e pensiero, 1992, p. 477-518.

FAVREAU, Robert (dir.). Corpus des inscriptions de la France médiévale, t. VI, Gers, Landes, Lot-et-Garonne, Pyrénées-Atlantiques, Paris: CNRS, 1981.

FREIGANG, Christian. La conception spatiale des chevets gothiques: points de vue liturgiques, In: FROMMEL, Sabine(dir.) \& LECOMTE, Laurent (dir.), La place du chour. Architecture et liturgie du Moyen Âge aux Temps modernes, Paris-Rome: PicardCampisano, 2012, p. 67-78. 
GABORIT, Michelle. Des Hystoires et des couleurs. Peintures murales médiévales en Aquitaine, Bordeaux: Éd. Confluences, 2002.

GUY, André. Les fresques de la chapelle de Lavaufranche. In: Mémoires de la société des sciences naturelles et archéologiques de la Creuse, t. 34, 1960-1962, p. 88-98.

HIGOUNET, Charles. Cartulaire des Templiers de Montsaunès. In: Bulletin philologique et historique du CTHS. Années 1955-1956, Paris, 1957, p. 211-294.

JEANTON, Gabriel. Les commanderies du Temple Sainte-Catherine de Montbellet et de Rougepont. In: Annales de l'Académie de Mâcon, t. XX, 1916-1917, p. 54-190.

JUIN, Florence; MARTIN, Pierre. La chapelle des Hospitaliers de Plaincourault. In: Art Sacré. Les cahiers de Rencontre avec le patrimoine religieux, $n^{\circ} 18,2003$, p. 7793.

LEGRAS, Anne-Marie; LEMAITRE, Jean-Loup. La pratique liturgique des Templiers et des Hospitaliers de Saint-Jean de Jérusalem. In: BOURLET, Caroline(dir.)\& DUFOUR, Annie(dir.), L'écrit dans la société médiévale, divers aspects de sa pratique du XI' au XV'e siècle, Paris: CNRS, 1991, p. 77-137.

LICENCE, Tom. The Templars and the Hospitallers, Christ and the Saints. In: Crusades, 4, 2005, p. 39-57.

LIZERAND, Georges. Le dossier de l'affaire des Templiers. Paris, 1923.

MACE, Laurent; POUSTHOMIS-DALLE, Nelly. Mémoire chevaleresque, mémoire des fondateurs ? Une sépulture de prestige chez les Hospitaliers de Toulouse (XIII' ${ }^{\mathrm{e}}$ siècle). In: ALDUC-LE BAGOUSSE, Armelle (dir.). Inhumations de prestige ou prestige de l'inhumation ? Expressions du pouvoir dans l'au-delà ( $\mathrm{IV}^{\mathrm{e}}-\mathrm{XV} \mathrm{e}$ siècle), Caen:

Publications du CRAHM, 2009, p. 357-381.

MATTALIA, Yoan. Les établissements des ordres religieux militaires aux XII' et XIII ${ }^{e}$ siècles dans les diocèses de Cahors, Rodez et Albi. Approche archéologique et historique, thèse de doctorat, Université de Toulouse 2-Le Mirail, 2013, 4 vols.

MIGUET, Michel. Templiers et Hospitaliers en Normandie. Paris: Comité des travaux historiques et scientifiques, 1995.

MORRIS, Colin. Picturing the Crusades: the Use of visual Propaganda, c. 1095-1250. In: FRANCE, John (dir.), ZAJAC, William (dir.) \& HAMILTON, Bernard (dir.). The Crusades and their Sources: Essays presented to Bernard Hamilton, AldershotBrookfield: Ashgate, 1998, p. 195-216.

NICHOLSON, Helen J. The Head of St Euphemia: Templar Devotion to Female Saints. In: EDGINGTON, Susan B. (dir.) \& LAMBERT, Sarah (dir.). Gendering the Crusades. New York: Columbia University Press, 2002, p. 108-120. 
NICHOLSON, Helen J. Saints venerated in the Military Orders. In: CZAJA, Roman(dir.); SARNOWSKY, Jürgen (dir.), Selbstbild und Selbstverständnis der geistlichen

Ritterorden. (Ordines Militares-Colloquia Torunensia Historica, XIII), Torun, 2005, p. 91-113.

D’Ocre et d'azur. Peintures murales en Bourgogne, Dijon: Musée archéologique de Dijon, 1992.

PALAZZO, Éric. Les peintures murales et les pratiques liturgiques dans l’Église médiévale. In: RUSSO, Daniel (dir.). Peintures murales médiévales, $\mathrm{XII}^{\mathrm{e}}-\mathrm{XVI}{ }^{\mathrm{e}}$ siècles. Regards comparés. Dijon: Éditions universitaires de Dijon, 2005, p. 57-62.

PALAZZO, Éric. Art et liturgie au Moyen Âge. Nouvelles approches anthropologiques et épistémologiques. In: Anales de Historia del Arte, Volumen Extraordinario, 2010, p. 31-74.

PIEL, Caroline. Creuse, Saint-Domet, chapelle de la Croix au Bost. Découverte de peintures murales. In: Bulletin monumental, t. 143, 1985, p. 56-6o.

PIZARRO GOMEZ, Francisco Javier (dir.). El Arte y las Ordenes Militares, Actas del Simposio (Cáceres, 26-27 de abril de 1985), Cáceres, 1985.

PURKIS, William J. Crusading Spirituality in the Holy Land and Iberia, c. 1095-c. 1187. Woodbridge: The Boydell Press, 2008.

ROSSI VAIRO, Giulia. Arte e architettura dei Teutonici in Italia: prospettive di ricerca. In: L'Ordine Teutonico tra Mediterraneo e Baltico: incontri e scontri tra religioni, popoli e culture. Convegno della Commissione Storica Internazionale per le ricerche sull'Ordine Teutonico (Bari-Lecce-Brindisi, 14-16 settembre 2006). Congedo: Galatina 2008, p. 219-236.

ROSSI VAIRO, Giulia. Arte da Ordem Teutónica. In: FERREIRA FERNANDES, Isabel Cristina (dir.). As Ordens Militares. Freires, Guerreiros, Cavaleiros. VI Encontro sobre Ordens Militares. Palmela (10 a 14 de março de 2010), Palmela: Município de Palmela/GEsOS, 2012, vol. II, p. 1009-1024.

SAINT-JEAN, Robert. La commanderie de Jalès: les bâtiments, XIIe-XVIIIe siècles. In: Revue du Vivarais, t. XCI, 1987, p. 53-70.

SALVADO, Sebastian. Interpreting the Altarpiece of Saint Bernard. Templar Liturgy and Conquest in Thirteenth-Century Majorca. In: Iconographica. Rivista di iconografia medievale e moderna, 5, 2006, p. 48-63.

SALVADO, Sebastian. Icons, Crosses and the Liturgical Objects of Templar Chapels in the Crown of Aragon. In: BURGTORF, Jochen (dir.); NICHOLSON, Helen (dir.); CRAWFORD, Paul (dir.). The Debate on the Trial of the Templars (1307-1314). Aldershot: Ashgate, 2010, p. 183-197. 
SALVADO, Sebastian. Templar Liturgy and Devotion in the Crown of Aragon. In: NICHOLSON, Helen (dir.). On the Margins of Crusading. The Military Orders, the Papacy and the Christian World. Farnham: Ashgate, 2011, p. 31-43.

SCHENK, Jochen G. Some Hagiographical Evidence for Templar Spirituality, Religious Life and Conduct. In: Revue Mabillon, n.s., t. 22, 2011, p. 99-119.

SCHENK, Jochen G. The Cult of the Cross in the Order of the Temple. In: FERREIRA FERNANDES, Isabel Cristina (dir.). As Ordens Militares. Freires, Guerreiros, Cavaleiros. VI Encontro sobre Ordens Militares. Palmela (10 a 14 de março de 2010), Palmela, Município de Palmela/GEsOS, 2012, vol. 1, p. 207-220.

SUAU, Jean-Pierre. Les scènes moralisatrices du bas du mur nord du chevet de l'église de Lugaut (Landes). In: Bulletin de la Société de Borda, 1993, p. 269-301.

THIBOUT, Marc. L’église de Lugaut et son décor mural. In: Bulletin monumental, 123, 1965, p. 37-44.

TOMMASI, Franceso. I Templari e il culto delle reliquie. In: MINNUCCI, Giovanni(dir.); SARDI, Franca (dir.). I Templari. Mito e storia. Atti del Convegno di Studi alla Magione Templare di Poggibonsi-Siena (29-31 maggio 1987), Sinalunga: A. G. Viti-Riccucci, 1989, p. 191-210.

TOOMASPOEG, Kristjan. I cavalieri templari e i giovanniti. In: RegulaeConsuetudines-Statuta. Studi sulle fonti normative degli ordini religiosi nei secoli centrali del Medioevo. Atti del I e del II Seminario internazionale di studio del Centro italotedesco di storia comparata degli ordini religiosi (Bari-Noci-Lecce, 26-27 ottobre 2002 / Castiglione delle Stiviere, 23-24 maggio 2003), Münster: Lit Verlag, 2005, p. 387-401.

TOUBERT, Hélène. Iconographie et histoire de la spiritualité médiévale. In: TOUBERT, Hélène. Un art dirigé. Réforme grégorienne et iconographie. Paris: Éd. du Cerf, 1990.

VAIVRE, Jean-Bernard de. Peintures murales disparues ou en péril d'anciennes chapelles de l'ordre des Hospitaliers. In: Comptes rendus de l'Académie des inscriptions et belles-lettres, 2006, p. 1037-1065

VOYER, Cécile. Histoire de l'art et anthropologie ou la définition complexe d'un champ d'étude. In: Faire l'anthropologie historique du Moyen Âge. Revue électronique du Centre de Recherches Historiques, 6, 2010, p. 1-10. 